\title{
PENINGKATAN PERAN ORANGTUA TERHADAP PEMBERIAN IMUNISASI SESUAI JADWAL DI MASA PANDEMIC COVID-19
}

\author{
Eviyani Margaretha Manungkalit ${ }^{1^{*}}$, Baharika Suci Dwi Aningsih ${ }^{2}$, Anjela \\ Marici $^{3}$, Alifia Nur Hidayah ${ }^{4}$, Eva Januarita Tatebburuk Oppemanai ${ }^{5}$ \\ ${ }^{1-5}$ STIK Sint Carolus
}

Email Korespondensi: evikalit@gmail.com

\begin{abstract}
ABSTRAK
Masa pandemi berdampak dalam pencapaian cakupan imunisasi dasar dan lanjutan di Indonesia. 80\% di 401 kabupaten/kota belum tercapai sepenuhnya, hanya 200 yang mencapai imunisasi dasar lengkap lebih dari 80\%. Salah satu penyebabnya karena kekhawatiran orangtua membawa anak ke layanan kesehatan untuk melakukan imunisasi. Tujuan kegiatan ini untuk meningkatkan pengetahuan orangtua terhadap pentingnya pemberian imunisasi pada bayi/balita sesuai jadwal. Kegiatan yang dilakukan berupa penyuluhan kepada orang tua yang memiliki bayi/balita secara virtual menggunakan media slide (power point), video, dan leaflet. Setelah dilakukan penyuluhan, terdapat peningkatan pengetahuan orang tua tentang imunisasi. Promosi Kesehatan merupakan salah satu bentuk intervensi yang dapat digunakan untuk meningkatkan wawasan serta didukung kebijakan publik. Orangtua/keluarga memiliki peran penting terhadap pencapaian cakupan imunisasi bagi bayi/balita untuk meningkatkan kekebalan tubuh anak dari setelah dilakukan penyuluhan tentang imunisasi penyakit menular yang dapat dicegah dengan imunisasi (PD3I).
\end{abstract}

Kata Kunci: Imunisasi, Jadwal, Peran Orang Tua

\begin{abstract}
The Pandemic Period has had an impact on achieving basic and advanced immunization coverage in Indonesia. About 80 percent of infants in 401 capital cities to the district were incompletely immunized, only 200 have favorably received complete basic immunization of more than 80 percent. One of the reasons is the parents were afraid to bring the toddler or infants to health facilities for vaccinations. This immunization activity typically aimed to increase a parent's knowledge in maintaining the punctuality of complete basic immunization of infants and toddlers. The immunization activities can be carried out by providing counseling to parents virtually using PowerPoint slides, videos, and distributing leaflets. After getting counseled, it is expected that there was an increase in parental knowledge about giving complete immunization. Health Promotion derives one form of intervention that can be used to increase knowledge and be supported by public policy. Parents should be aware of the importance of immunization coverage that provides immunity
\end{abstract}


to infants or toddlers to suppress the infectious diseases that can be prevented by immunization.

Keywords: immunization, schedule, the role of parents

\section{PENDAHULUAN}

Pandemi Corona Virus-19 (COVID-19) berdampak pada pemberian layanan kesehatan, salah satunya adalah pelayanan kesehatan pada program Imunisasi (Kemenkes RI dan UNICEF, 2020). Pemerintah Indonesia telah melakukan sejumlah strategi untuk mencegah dan mengendalian COVID-19 serta peningkatan sistem kesehatan. Upaya yang diilaksanakan diantaranya adalah physical distancing (menjaga jarak aman 1-2 meter), membatasi perjalanan domestik dan internasional, pelarangan kegiatan berkumpul atau berkelompok; dan lain sebagainya. Namun, hal ini berdampak pada pemberian layanan imunisasi (Kemenkes RI, 2020)

Kebijakan pembatasan pergerakan (physical distancing), sistem kesehatan yang berhubungan dengan pandemik menyebabkan terjadinya penurunan angka cakupan dan kebutuhan akan vaksinasi. Layanan imunisasi mengalami gangguan di 84\% fasilitas Kesehatan akibat pandemi (Kemenkes dan UNICEF, 2020). Hal ini dapat menyebab adanya resiko bayi balita terpapar penyakit menular yang dapat dicegah dengan imunisasi (PD3I).

Imunisasi merupakan suatu upaya untuk meningkatkan sistem kekebalan seseorang terhadap suatu penyakit (WHO, 2013). Imunisasi terbagi atas imunisasi dasar dan imunisasi lanjutan. Salah satu imunisasi dasar adalah MR, yaitu Measles Rubela diberikan pada usia 9 - 12 bulan untuk mencegah penyakit campak dan rubella. Penyakit ini dapat menyebabkan komplikasi berat jika kondisi daya tahan tubuh anak menurun terutama dengan status gizi kurang, yaitu kebutaan, ensefalitis, diare parah, infeksi telinga dan radang paru-paru (Novikasari dkk, 2019).

Cakupan Imunisasi Dasar Lengkap di Indonesia pada Tahun 2019 sebesar 93.7\% (Kemenkes RI, 2020). Persentase Imunisasi Dasar Lengkap ini telah memenuhi target Rencana Strategis Kementrian Kesehatan 2020-2024 yaitu sebesar $90 \%$ (Permenkes, 2020). Persentase kabupaten/kota yang mencapai $80 \%$ imunisasi dasar lengkap anak usia 0-11 bulan sebesar $95 \%$. Namun, akibat pandemi COVID-19 target cakupan 80\% di 401 kabupaten/kota belum tercapai sepenuhnya, hanya 200 yang mencapai imunisasi dasar lengkap lebih dari 80\% (Kemenkes RI, 2020). Faktor-faktor yang mempengaruhi ketidaktercapaian cakupan imunisasi bayi balita antara lain penolakan terhadap imunisasi dengan berbagai alasan, ketidaktahuan orang tua terkait manfaat imunisasi, kekhawatiran orang tua untuk membawa bayi balita ke fasilitas Kesehatan di masa pandemic Covid-19 (Kemenkes RI, 2020).

Hasil suvey yang dilakukan oleh Kemenkes bersama UNICEF pada 12.641 orangtua dan pengasuh diperoleh hasil $23 \%$ memutuskan tidak membawa anak untuk vaksinasi, 13\% ragu-ragu, selain itu, cakupan vaksinasi rubella (MR1) dan campak berkurang > 35\% (Kemenkes dan UNICEF, 2020). Pemerintah melakukan strategi untuk mengatasi persepsi masyarakat tentang imunisasi khususnya pada orang tua dan pengasuh. Salah satu strategi yang dilakukan dengan cara menyebarluaskan materi KIE menggunakan media sosial, media lokal maupun platform lainnya mengenai jadwal imunisasi, manfaat imunisasi, serta pemberian imunisasi tepat waktu (informasi kepada masyarakat mengenai imunisasi (Kemenkes RI dan Unicef, 2020). Berdasarkan hasil 
penelitian Faridah BD, dkk (2019) menyatakan media slide lebih efektif dari pada leaflet dalam meningkatkan pengetahuan dan sikap ibu tentang Imunisasi.

Berdasarkan latar belakang diatas, penulis tetarik untuk melakukan kegiatan penyuluhan di wilayah kerja Puskesmas Johar Baru. Kegiatan ini merupakan salah satu upaya untuk meningkatkan pengetahuan dan motivasi orangtua/keluarga agar membawa anaknya untuk memperoleh layanan imunisasi.

\section{MASALAH}

Dari hasil pengkajian data di wilayah kerja puskesmas johar baru 2, cakupan imunisasi dasar sebesar $90 \%$ pada Tahun 2019. Hal ini masih belum mencapai target yang telah ditentukan. Berdasarkan hal tersebut, perlu diadakannya promosi kesehatan tentang imunisasi. Kegiatan Penyuluhan kepada Masyarakat ini bertujuan untuk meningkatkan pengetahuan orang tua pentingnya imunisasi bayi dan balita.

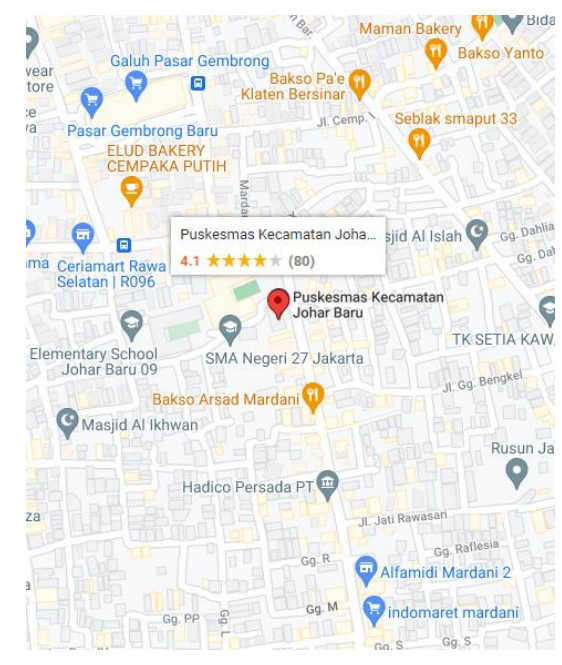

Gambar 2.1 Peta Lokasi Kegiatan Pengabdian Kepada Masyarakat

\section{METODE}

\section{a. Tujuan Persiapan}

Kegiatan diawali dengan melakukan melakukan pengkajian data terkait cakupan imunisasi di wilayah kerja Puskesmas Johar Baru. Pembuatan dan pengusulan proposal kegiatan untuk memperoleh izin pelaksanaan kegiatan. Membuat materi, formulir daftar hadir, kuesioner, penjadwalan link zoom dan melakukan pendampingan kepada orang tua yang memiliki bayi balita. Media penyampaian penyuluhan imunisasi menggunakan slide (power point), video, dan leaflet. Persiapan dan pendampingan dilakukan pada tanggal 20 - 24 November 2020 Pukul 08.00 - 10.00 wib.

\section{b. Tahap Pelaksanaan}

Pelaksanaan kegiatan ini bekerjasama dengan Puskesmas dan Kader Kesehatan setelah melakukan pengkajian data terkait cakupan imunisasi serta memperoleh izin dari Puskesmas Johar Baru. Sasaran kegiatan adalah Ibu yang mempunyai bayi balita. 


\section{c. Evaluasi}

i. Struktur

Kegiatan Pengabdian kepada Masyarakat dilaksanakan dengan menggunakan platform Zoom Meeting's Cloud. Jumlah peserta yang mengikuti kegiatan sebanyak 29 orang. Penyuluhan berlangsung dengan sangat baik menggunakan bahasa serta cara komunikasi dan media yang interaktif sehingga mudah dipahami oleh peserta. Selain itu, peserta diberi kesempatan untuk bertanya dan melakukan sharing/diskusi tentang imunisasi.

ii. Proses

Kegiatan penyuluhan kesehatan ini dilaksanakan sesuai jadwal yang telah direncanakan, berlangsung pada Pukul 12.30 - 14.30 wib.

\section{HASIL DAN PEMBAHASAN}

Kegiatan Pengabdian kepada Masyarakat diikuti oleh 29 peserta. Rerata umur peserta adalah 28 tahun dengan rentang usia 20 tahun sampai dengan 59 tahun. Hampir seluruh peserta (90.5\%) yang ikut dalam kegiatan penyuluhan memiliki latar belakang pendidikan terakhir yaitu SMA/ Sederajat, bekerja sebagai ibu rumah tangga (86.36\%), dan sebagian kecil bekerja sebagai karyawan swasta (4.55\%) serta wirausaha (9.09\%).

Peserta dilakukan pretest sebelum pelaksanaan penyuluhan dan posttest setelah pelaksanaan penyuluhan untuk mengetahui tingkat pengetahuan dan pemahaman mengenai Imunisasi. Katagori tingkat pengetahuan dan pemahaman diklasifikasikan dengan rincian sebagai berikut: Pengetahuan baik 76-100\%, pengetahuan cukup 56-75\% dan pengetahuan kurang dari $56 \%$. Berikut hasil perbandingan tingkat pengetahuan sasaran terkait Imunisasi, sebelum dan setelah dilakukan kegiatan dengan metode penyuluhan:

Tabel 1. Persentase Perbandingan Tingkat Pengetahuan Peserta sebelum diberikan Penyuluhan dan Setelah dilakukan Penyuluhan

\begin{tabular}{ccc}
\hline TINGKAT & PRESTEST & POSTEST \\
PENGETAHUAN & $9.1 \%$ & $63.6 \%$ \\
\hline BAIK & $54.5 \%$ & $36.4 \%$ \\
\hline CUKUP & $36.4 \%$ & $0 \%$ \\
\hline KURANG &
\end{tabular}

Berdasarkan perbadingan hasil jawaban peserta antara hasil pretest dan posttest didapatkan rerata tingkat pengetahuan dan pemahaman peserta pada pretest adalah 59.9 \% (tingkat pemahaman cukup) sedangkan rerata tingkat pengetahuan dan pemahaman setelah dilakukan penyuluhan $88 \%$ (tingkat pengetahuan baik). Rerata selisih peningkatan pengetahuan dan pemahaman yaitu sebesar $27.74 \%$.

Media yang digunakan selama penyuluhan menggunakan media slide (power point), video, dan leaflet untuk memaparkan materi terkait imunisasi. Penentuan Jenis media yang digunakan sangat membantu untuk melakukan penyuluhan Kesehatan serta bertujuan untuk meningkatkan kemampuan individu, keluarga, atau kelompok dalam upaya Kesehatan (Nurmala, 2018). 
Promosi Kesehatan dengan pemberian materi melalui media slide disertai gambar, video dan audio dapat meningkatkan pengetahuan peserta. Hal ini sejalan dengan penelitian Farida BD, dkk (2018), yang menyatakan bahwa media slide lebih efektif dari pada media leaflet dalam meningkatkan pengetahuan dan sikap ibu. Penelitian serupa juga menjelaskan bahwa peningkatan pengetahuan berhubungan dengan perubahan sikap seseorang, dimana sikap merupakan faktor yang paling dominan jika dihubungkan dengan kelengkapan status imunisasi bayi, selain faktor pekerjaan, pendidikan dan tingkat pengetahuan (Suhaid dan Fransiska, 2018)

Berikut dokumentasi pelaksanaan kegiatan pengabdian kepada masyarakat:

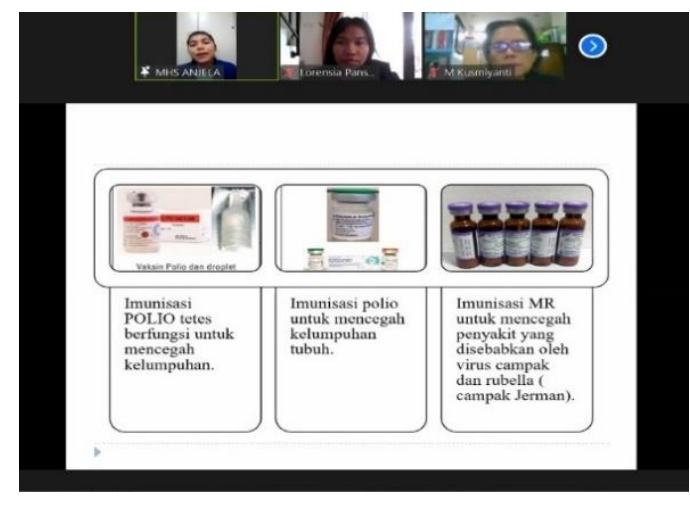

Gambar 4.1 Edukasi Imunisasi

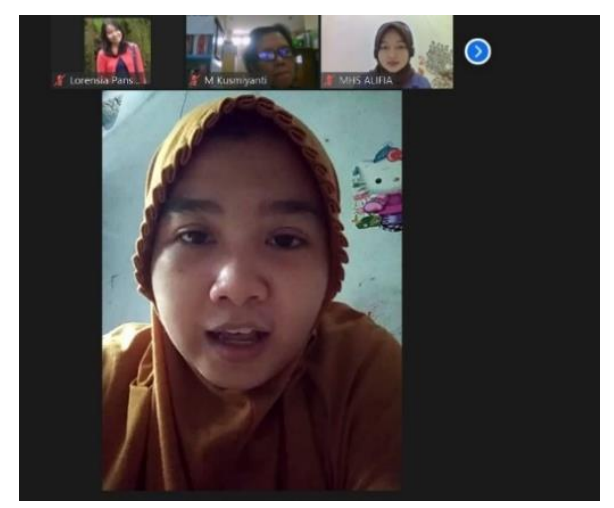

Gambar 4.2 Peserta bertanya terkait Imunisasi 


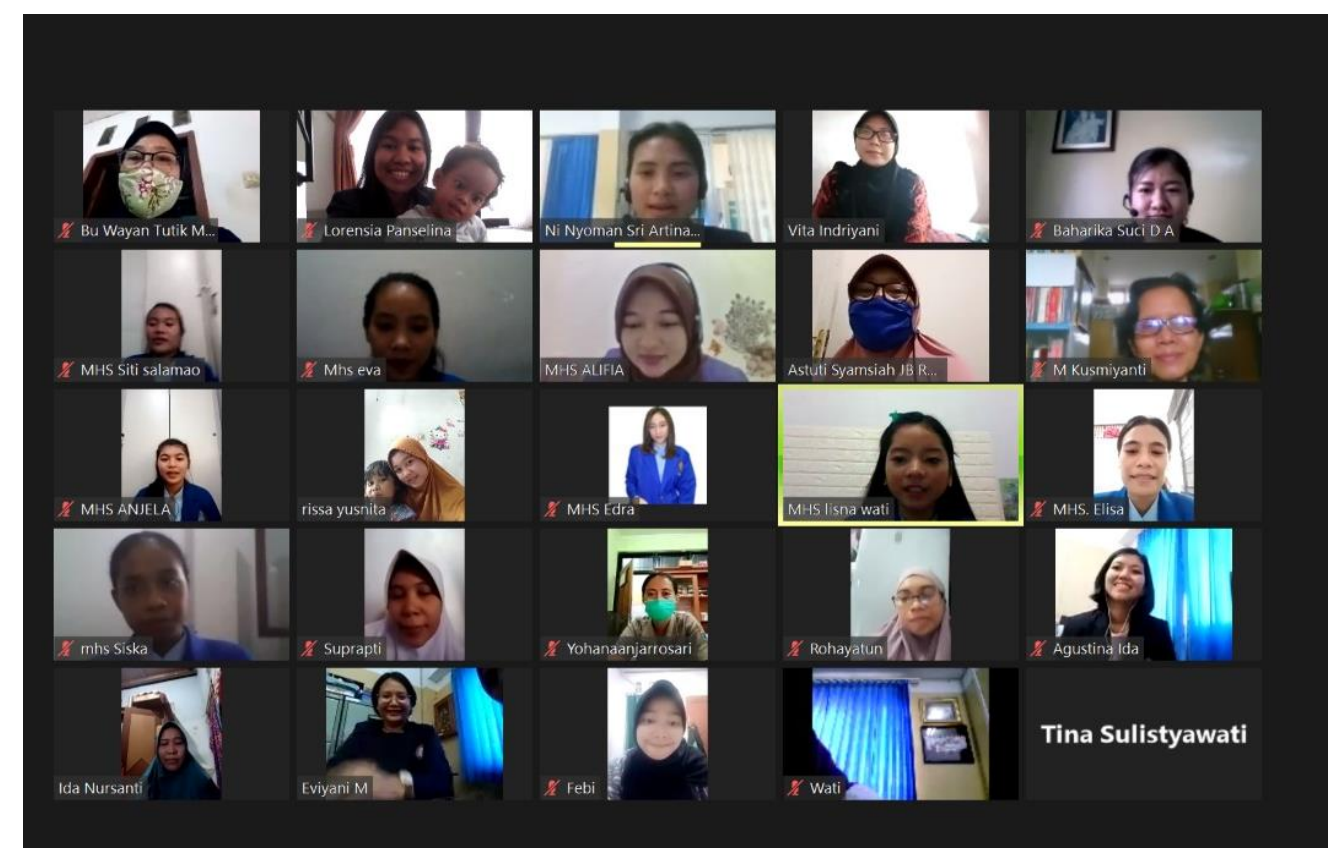

Gambar 4.3 Peserta dan Pelaksana Pengabdian kepada Masyarakat

\section{KESIMPULAN}

Promosi Kesehatan merupakan salah satu bentuk intervensi dalam Kesehatan masyarakat kepada seseorang atau komunitas yang bertujuan untuk meningkatkan wawasan serta didukung kebijakan publik. Berdasarkan pelaksanaan kegiatan yang telah dilakukan, terdapat peningkatan pengetahuan dan pemahaman orangtua/keluarga setelah dilakukan penyuluhan tentang imunisasi. Pemberian imunisasi dasar maupun lanjutan harus dilaksanakan sesuai jadwal dan rekomendasi dari tenaga kesehatan. Hal ini bertujuan agar bayi dan balita terlindungi dari penyakit infeksi yang berbahaya. Orangtua/keluarga berperan penting terhadap program imunisasi yang telah ditetapkan pemerintah dengan cara memastikan anak dalam kondisi sehat untuk diimunisasi, menyiapkan buku KIA atau catatan imunisasi anak, melakukan pendaftaran dan pelaksanaan layanan imunisasi sesuai protokol kesehatan yang telah ditetapkan pemerintah.

\section{DAFTAR PUSTAKA}

Bd, F., Susanti, D., \& Hidayah, R. (2019). Perbedaan Efektivitas Promosi Kesehatan dengan Media Leaflet dan Slide Terhadap Tingkat Pengetahuan dan Sikap Ibu Tentang Imunisasi Measles Rubella Di Posyandu Bahari IV Dan V Lubuk Buaya Kota Padang Tahun 2019. Jurnal Kesehatan Mercusuar, 2(1), 5 pages. https: //doi.org/10.36984/jkm.v2i1.38

Kemenkes RI. (2020). Profil Kesehatan Indonesia Tahun 2019. Jakarta; Kemenkes https: / /pusdatin.kemkes.go.id/resources/download/pusdatin/profilkesehatan-indonesia/Profil-Kesehatan-indonesia-2019.pdf. 
Kemenkes RI. (2020). Petunjuk Teknis Pelayanan Imunisasi pada Masa Pandemi Covid-19. https: / /www.who.int/docs/defaultsource/searo/indonesia/covid19/juknis-pelayanan-imunisasi-padamasa-pandemi-covid-19.pdf?sfvrsn=cf2391f2__.

Kemenkes RI dan Unicef.(2020). Routine Immunization for Children during the COVID-19 Pandemic in Indonesia: Perceptions of Parents and Caregivers.

https://www.unicef.org/indonesia/media/6066/file/Routine\%20imm unization\%20for\%20children\%20during\%20the\%20COVID-

19\%20pandemic\%20in\%20Indonesia:\%20Perceptions\%20of\%20parents\%2 0and\%20caregivers.pdf.

Kemenkes RI dan Unicef. (2020). Penilaian Cepat: Dampak Pandemi Covid-19 terhadap Layanan Imunisasi di Indonesia. https: / / covid19.go.id/storage/app/media/Materi\%20Edukasi/2020/M ei/immunization-rapid-assessment-id-19-05-2020.pdf

Novikasari, Linawati., Zainaro, M Arifki., Wardiyah, Aryanti., dan Eka Trismiyana. (2019). Penyuluhan Kesehatan tentang Pentingnya Imunisasi MR (Measles Rubela) Di Puskesmas SImpur Bandar Lampung. Jurnal Kreativitas Pengabdian kepada Masyarakat, 2(2), 133-138. http://ejurnalmalahayati.ac.id/index.php/kreativitas/article/view/2 $\underline{077 .}$

Mukti, Arifas Septiane dan Asri Aprilia. (2020). Faktor-Faktor yang Berhubungan dengan Rendahnya Cakupan Imunisasi BCG di Wilayah Kerja Puskesmas Sadananya. Jurnal Kesehatan Bakti Tunas Husada: Jurnal Ilmu Keperawatan, ANalisis Kesehatan dan Farmasi, 20(01), 1120.

https://ejurnal.stikesbth.ac.id/index.php/P3M_JKBTH/article/view/ $\underline{549}$.

Nurmala, Ira., Rahman, Fauzie., Nugroho, Adi., Erlyani, Neka., Laily, Nur., dan Vina Yulia Anhar. (2018). Promosi Kesehatan. Surabaya; Airlangga University Press.

Peraturan Menteri Kesehatan Republik Indonesia Nomor 21 Tahun 2020 tentang Rencana Strategis Kementrian Kesehatan Tahun 2020-2024. https://gizi.kemkes.go.id/katalog/pmk-no-21-th-2020-ttg-rencanastrategis-kementerian-kesehatan-tahun-2020-2024.pdf

Suhaid, Dewi Novitasari dan Fransisca Faranita. (2018). Faactor Associated with Basic Immunization Status of Infant. The Southeast Asia Journal of Midwifery, 4(1), 32-39. http://www.journalaipkind.or.id/index.php/seajom/article/view/26.

WHO. (2013). Vaccine Safety Basics Learning Manual. https://www.who.int/vaccine_safety/initiative/tech_support/Vaccin e-safety-E-course-manual.pdf 